\title{
Plant Growth as Affected by Concomitant Movement of Arsenic and Sulphur in Saline Soils
}

\author{
Sayeda Sabrina Ali, Monira Begum, Shah Muhammad Imamul Huq* \\ Department of Soil, Water and Environment, University of Dhaka, Dhaka, Bangladesh \\ Email: "imamhuq@hotmail.com
}

Received 9 March 2016; accepted 18 April 2016; published 21 April 2016

Copyright (C) 2016 by authors and Scientific Research Publishing Inc.

This work is licensed under the Creative Commons Attribution International License (CC BY).

http://creativecommons.org/licenses/by/4.0/

(c) (i) Open Access

\begin{abstract}
A study was carried out to assess the interaction of Arsenic with excess Sulphur present in saline soil and their impact on plant growth. Two different types of saline soils $S_{1}(2.0 \mathrm{dS} / \mathrm{m})$ and $S_{2}$ $(5.061 \mathrm{dS} / \mathrm{m})$ were collected from the southwestern part of Bangladesh. The experiment was conducted in two parts: in vitro incubation study and pot experiment. Arsenic treatments at the rates of $0,0.05$ and $1.0 \mathrm{mg} / \mathrm{L}$ were applied with water. The incubated soils were sequentially extracted with three different extractants, viz, distilled water, $0.01 \mathrm{M} \mathrm{CaCl}_{2}$, and $1 \mathrm{M} \mathrm{HCl} .1 \mathrm{M} \mathrm{HCl}$ was found to extract the maximum amounts of soluble salts as well as arsenic from the saline soil. Rice was selected as the test plant for pot experiment. An improved variety of rice (BRRI 41) was grown on the experimental soils. Sulphur in saline soil was found to reduce the accumulation of Arsenic by rice plant.
\end{abstract}

\section{Keywords}

Sulphur, Arsenic, Saline Soil, Rice

\section{Introduction}

Arsenic (As) is a toxic metalloid element in ground and surface waters [1]. Groundwater contamination by As has been reported in 20 countries of the world, encompassing all the continents [2], but the extent of groundwater contamination in Bangladesh is by far the most severe, as it covers almost $80 \%$ of the country. It has been proved beyond doubt that the origin of arsenic in groundwater in Bangladesh is geogenic [3]. The development of strongly reducing condition is believed to be responsible for the release of naturally occuring arsenic from the

${ }^{*}$ Corresponding author. 
sediment into the ground water. Rice is the staple crop of 3 billion people worldwide and Asian countries account for $90 \%$ of its production as well as consumption [4]. Unlike other cereal crops, rice is particularly efficient in As (III) accumulation and for that impaired cellular functions through strapping of sulfhydryl groups of enzymes and proteins occur [1]. In addition, inhibition of SH containing enzymes by As alters cellular redox state and finally leads to cytotoxicity [5].

A large part of the soils of Bangladesh in the southern coastal areas are afflicted with the problem of salinity. The impact of climate change has aggravated the severity of salinity in soils. During the last 40 years it has been increased by $26 \%$ [6]. Sulphate ( $\mathrm{SO}_{4}^{2-}$ ) is one of the principal soluble anions in saline soil and sulphur (S) is an essential nutrient element for plant. It is one of the components of sulphur amino acids (cysteine and methionine) and many other compounds, e.g. glutathione or ferredoxin, which play important physiological functions [7]. But excessive $\mathrm{S}$ in soil, which is associated with salinity, might have impact on plant function. With the increase in Sulphate ion accumulation in the nutrient solution, their uptake by plants increases. Having reached a certain level, varying with plant species, further increase of concentration does not affect the uptake any longer. However, high Sulphate concentrations may affect plant development and crop yield [8]. High content of S in soil causes soil contamination and acidification too. Besides, it is indirectly responsible for mobilization of phytotoxic chemicals, such as aluminum and some trace elements [9].

During the dry season ground water moves upward by capillary action and leaves As in the soil. In addition, dry season aggravate salinity condition too. Though $\mathrm{S}$ has some functions of notable meditative effect to both plants' environmental stress and heavy metal pollution [10], our knowledge on interaction of As with $S$ in saline soil is limited. Therefore, this research attempt was initiated to investigate the interactions of As and S under in vitro incubation as well as in vivo pot culture experiment.

\section{Materials and Methods}

\subsection{Soil Sampling}

Soil samples were collected from four sampling sites of Khulna, a district situated in the southern part of the country. The soils belong to two representative soil series namely Dumuria and Bajoa series. According to USDA Soil Taxonomy all the series belong to Typic Endoaquepts subgroup. The georeferences of the sampling sites are presented in Table 1. Both the soil series belong to "Calcareous Grey" Soils of "Ganges Tidal Floodplain” physiography.

The soil samples were collected following the standard procedures [11]. The collected samples were air dried, debris were removed and larger aggregates were ground by gently crushing with a wooden hammer. Then the ground samples were sieved by passing through a $0.5 \mathrm{~mm}$ and $5 \mathrm{~mm}$ stainless steel sieve for in-vitro incubation experiment and pot experiments respectively.

\subsection{Experimental Set-Up}

\subsubsection{Incubation Experiment}

The incubation experiment was done using two types of saline soils. Arsenic treatments at the rates of $0,0.05$ and $1.0 \mathrm{mg} / \mathrm{L}$ were applied while, the incubation periods were 0,30 and 60 days. A combination of sodium meta arsenite $\left(\mathrm{NaAsO}_{2}\right)$ and sodium arsenate $\left(\mathrm{Na}_{2} \mathrm{HAsO}_{4} \cdot 7 \mathrm{H}_{2} \mathrm{O}\right)$ at a proportion of $80: 20$ were used to prepare the

Table 1. GPS location of the collected soil samples.

\begin{tabular}{|c|c|c|c|c|}
\hline & \multicolumn{2}{|c|}{ Soils for incubation experiment } & \multicolumn{2}{|c|}{ Soils for pot experiment } \\
\hline & $\mathrm{S}_{1}(2-4 \mathrm{dS} / \mathrm{m})$ & $\mathrm{S}_{2}(4-8 \mathrm{dS} / \mathrm{m})$ & $\mathrm{S}_{1}(2-4 \mathrm{dS} / \mathrm{m})$ & $\mathrm{S}_{2}(4-8 \mathrm{dS} / \mathrm{m})$ \\
\hline GPS location & $\begin{array}{c}22^{\circ} 48^{\prime} 50^{\prime \prime} \text { and } \\
89^{\circ} 29^{\prime} 32^{\prime \prime}\end{array}$ & $\begin{array}{c}22^{\circ} 47^{\prime} 45^{\prime \prime} \text { and } \\
89^{\circ} 26^{\prime} 55^{\prime \prime}\end{array}$ & $\begin{array}{c}22^{\circ} 47^{\prime} 39.1^{\prime \prime} \text { and } \\
89^{\circ} 27^{\prime} 30.3^{\prime \prime}\end{array}$ & $\begin{array}{c}22^{\circ} 46^{\prime} 17.7^{\prime \prime} \text { and } \\
89^{\circ} 28^{\prime} 10.3^{\prime \prime}\end{array}$ \\
\hline District & Khulna & Khulna & Khulna & Khulna \\
\hline Soil series & Dumuria & Bajoa & Bajoa & Bajoa \\
\hline Determined EC & 2.0 & 5.1 & 2.1 & 5.2 \\
\hline
\end{tabular}


treatment water. Plastic pots (250 g in size) were used and each pot was filled with $100 \mathrm{~g}$ soils. Then the pots were subjected to incubation with required doses of arsenic treatments at field moisture condition for the required time of incubation. At the end of each incubation period, the soils in each of the pots were mixed thoroughly for ensuring uniform sampling. Then the soil samples from each of the pots were collected randomly for further analysis. The $\mathrm{pH}$ and EC were measured following the standard procedures described in Imam and Didar [12].

The extractability of $\mathrm{S}$ and Asof the soils were determined by sequential extraction process. Three different extractants viz, $\mathrm{H}_{2} \mathrm{O}, 0.01 \mathrm{M} \mathrm{CaCl}_{2}$ [13] and $1 \mathrm{M} \mathrm{HCl}$ [14] were used for extraction of the elements from the soils sequentially in the order as mentioned above [15]. Content of Sulphur and arsenic in the above mentioned samples were determined following turbidimetric method [12] and HG-AAS technique [16] respectively.

\subsubsection{Pot Experiment}

The pot experiment was carried out in a net house using air dried soil in earthen pots. The pots (with $4 \mathrm{~kg}$ soil) were arranged following completely randomized design and they were regularly shuffled for proper light allocation. An improved variety of rice (BRRI 41) was used as the test variety and the seeds were sown directly on the soil. BRRI 41 rice failed to grow on $\mathrm{S}_{2}$ soil. Fertilizer (N, P and $\mathrm{K}$ ) requirement was calculated following the fertilizer recommendation guide [17]. Seedling emerged after 7 days of sowing. The same arsenic solution which was used for incubation experiment was also used for pot experiment. All treatments were repeated three times and total number of pots was 12. Pots were watered daily with arsenic laden irrigation water to keep them water logged. The plants were harvested manually after 110 days of seed sowing. After harvesting, the plants were cleaned by washing with tap water followed by deionized distilled water for three times and soaked with paper towel and then fresh weight was taken. The plant samples were separated into three parts-roots, stems and grains and then kept in an oven at a temperature of $70^{\circ} \mathrm{C} \pm 5^{\circ} \mathrm{C}$ for 72 hours. Dry weights as well as 1000 grain weights of the samples were recorded after that. The plant samples were crushed and sifted through a $0.2 \mathrm{~mm}$ sieve and stored in pots for further chemical analyses. Samples of rice root, stem and grain were digested with conc. nitric acid in block digester [16] [18]. This extract was used for the determination of S and As content of the plant samples. The quality control/quality assurance (QC/QA) of the analyses was maintained following the standard procedure. Statistical analysis was done by using Microsoft Excel (2010) version.

\section{Results and Discussions}

\subsection{Initial Characteristics of the Soil}

Some common physical and chemical properties were analyzed Table 2 before the experimental setup, in order to know the initial status of the soil. In soils used for incubation experiment, both $S$ and As contents were higher in $S_{2}$ soil than $S_{1}$ soil while, in the soils for pot experiment, $S_{1}$ soil contained more As and less $S$ than $S_{2}$.

\subsection{Interaction of $S$ with As in Soil}

The incubation experiment showed that Figure 1, without arsenic treatment both distilled water $\left(\mathrm{H}_{2} \mathrm{O}\right)$ and 0.01

Table 2. Initial characteristics of soil.

\begin{tabular}{|c|c|c|c|c|}
\hline \multirow{2}{*}{ Soil properties } & \multicolumn{2}{|c|}{ Soils for incubation experiment } & \multicolumn{2}{|c|}{ Soils for pot experiment } \\
\hline & $\mathrm{S}_{1}$ Soil & $\mathrm{S}_{2}$ Soil & $\mathrm{S}_{1}$ Soil & $\mathrm{S}_{2}$ Soil \\
\hline $\mathrm{pH}$ & 6.4 & 7.3 & 6.3 & 7.3 \\
\hline $\mathrm{EC}(\mathrm{dS} / \mathrm{m})$ & 2.0 & 5.06 & 2.1 & 5.2 \\
\hline Available N (\%) & 0.16 & 0.12 & 0.22 & 0.13 \\
\hline Available P (mg/kg) & 2.32 & 15.51 & 7.67 & 9.64 \\
\hline Available K (me/100 g) & 0.02 & 0.04 & 0.03 & 0.1 \\
\hline Available S (mg/kg) & 337.4 & 558.4 & 100.3 & 253.8 \\
\hline Total As (mg/kg) & 0.32 & 0.76 & 3.03 & 2.8 \\
\hline
\end{tabular}


$\mathrm{M} \mathrm{CaCl}_{2}$ extracted the minimum amount of As as well as S. Besides, among the three incubation periods, release of $\mathrm{S}$ was increased initially and then reduced. However, $1 \mathrm{M} \mathrm{HCl}$ extracted much higher amounts of $\mathrm{S}$ and As than either $0.01 \mathrm{M} \mathrm{CaCl}_{2}$ or $\mathrm{H}_{2} \mathrm{O}$.

Treatment of As at a rate of $0.05 \mathrm{mg} / \mathrm{L}$ showed that Figure 2, extractability of As by $0.01 \mathrm{M} \mathrm{CaCl}_{2}$ for As decreased with increased amount of extracted $\mathrm{S}$ in any of the three incubation periods. While sequential extraction with $\mathrm{H}_{2} \mathrm{O}$ and $1 \mathrm{M} \mathrm{HCl}$ showed that extractability of As increased with the increase in incubation period. However, $\mathrm{S}$ extraction showed an initial decrease after 30 days of incubation and then a steep increase after 60 days of incubation.

Incubation with the highest concentration of As i.e, $1 \mathrm{mg}$ As/L Figure 3 showed that $0.01 \mathrm{M} \mathrm{CaCl}_{2}$ extracted similar amounts of $\mathrm{S}$ and As as for $0.05 \mathrm{mg}$ As/L treatment. On the other hand, both $\mathrm{H}_{2} \mathrm{O}$ and $1 \mathrm{M} \mathrm{HCl}$ extracted higher amounts of $\mathrm{S}$ and As from the soil. Extractability by $1 \mathrm{M} \mathrm{HCl}$ for $\mathrm{S}$ and As was found to be the best followed by $\mathrm{H}_{2} \mathrm{O}$ for $\mathrm{S}_{1}$ soil. There was no significant correlation between extracted As and $\mathrm{S}$ except for $1 \mathrm{M} \mathrm{HCl}$ extracted ones(r value $=0.5873, \mathrm{p}<0.05)$. Moreover, the extracted amount of $\mathrm{S}$ was always found to be lower than the initial $\mathrm{S}$ content of the $\mathrm{S}_{1}$ soil i.e, $337.37 \mathrm{mg} / \mathrm{kg}$.

In the $S_{2}$ soil Figure 4, without arsenic treatment, the three extractants failed to extract As irrespective of the incubation periods. The test soil contained some As and the extraction of arsenic was very little either by $\mathrm{H}_{2} \mathrm{O}$ or $1 \mathrm{M} \mathrm{HCl}$ upto 30 days of incubation while no arsenic was found at the end. It needs to be mentioned here that extraction of As by $\mathrm{CaCl}_{2}$ was always lower. However, in all the cases, concentration of $\mathrm{S}$ was much greater and was in an increasing trend with the decreasing concentration of As for the three incubation periods.

Treatment of $\mathrm{S}_{2}$ soil with arsenic at a concentration of $0.05 \mathrm{mg} \mathrm{As} / \mathrm{L}$ Figure 5 and $1 \mathrm{mg}$ As/L Figure 6 showed a similar result like the control. Extractability of the three extractants followed a declining trend to extract As with the increase of incubation period. Extractability of $S$ was found to be much less than the control with any of the extractants and the extracted amount of $\mathrm{S}$ was lower than the background $\mathrm{S}$ content of the $\mathrm{S}_{2}$ soil i.e, $558.42 \mathrm{mg} / \mathrm{kg}$. Moreover, the correlation analysis between the extracted $\mathrm{S}$ and $\mathrm{As}$ in $\mathrm{S}_{2}$ soil showed that there was no significant interaction between As and S.

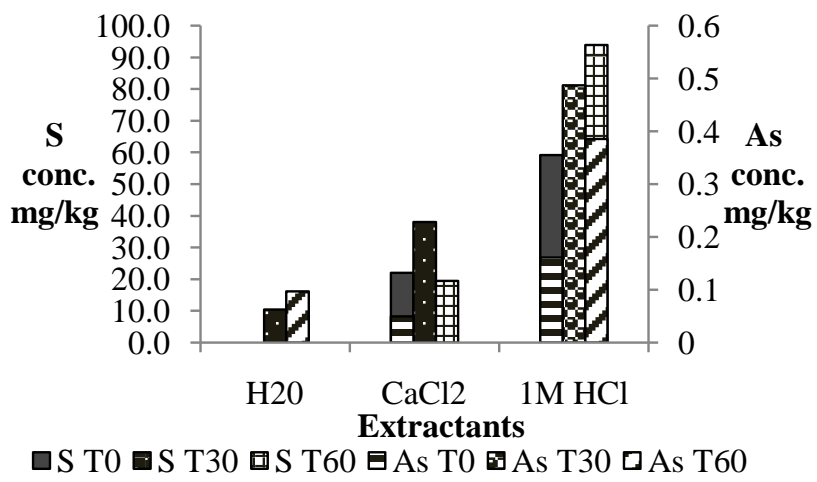

Figure 1. S-As interaction in treatment $\mathrm{As}_{0}$ in $\mathrm{S}_{1}$ soil.

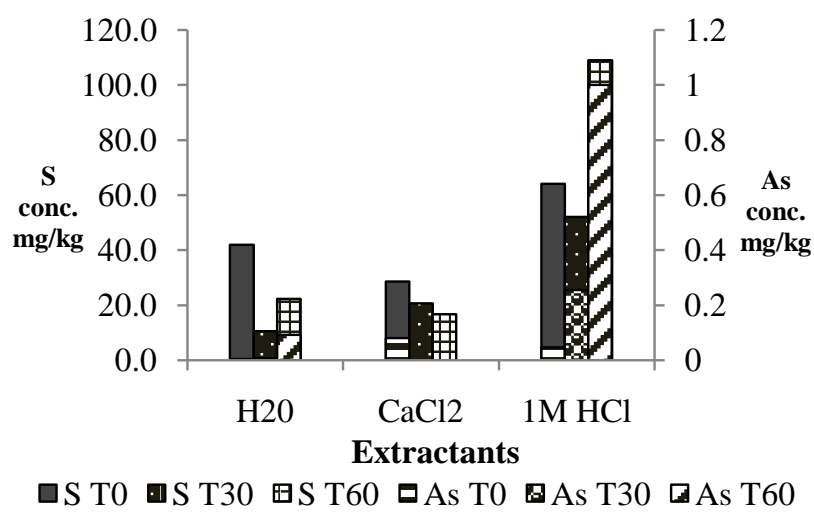

Figure 2. S-As interaction in treatment $\mathrm{As}_{0.05}$ in $\mathrm{S}_{1}$ soil. 


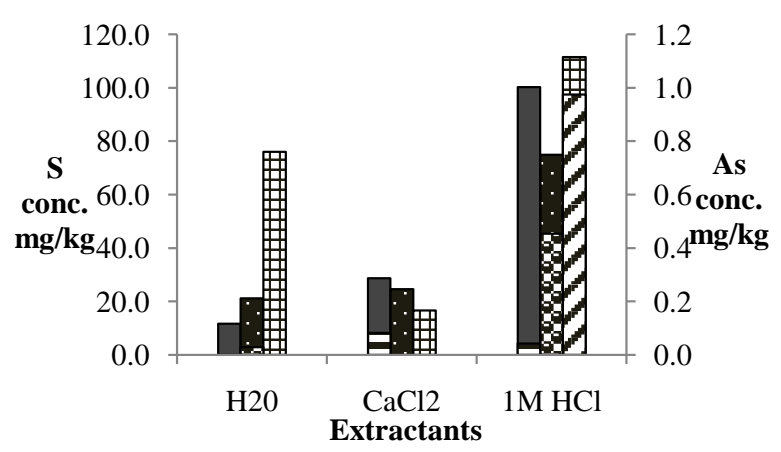

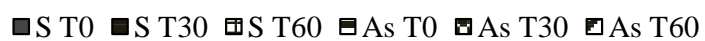

Figure 3. S-As interaction in treatment in $\mathrm{As}_{1}$ in $\mathrm{S}_{1}$ soil.

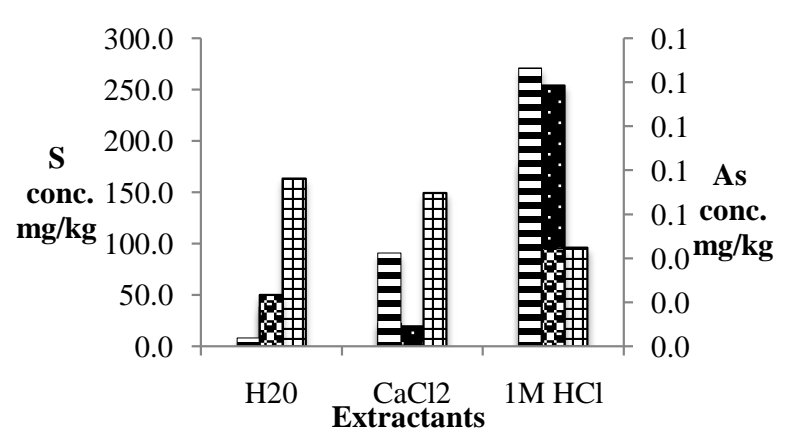

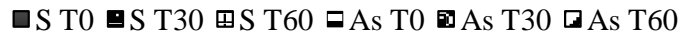

Figure 4. S-As interaction in treatment $\mathrm{As}_{0}$ in $\mathrm{S}_{2}$ soil.

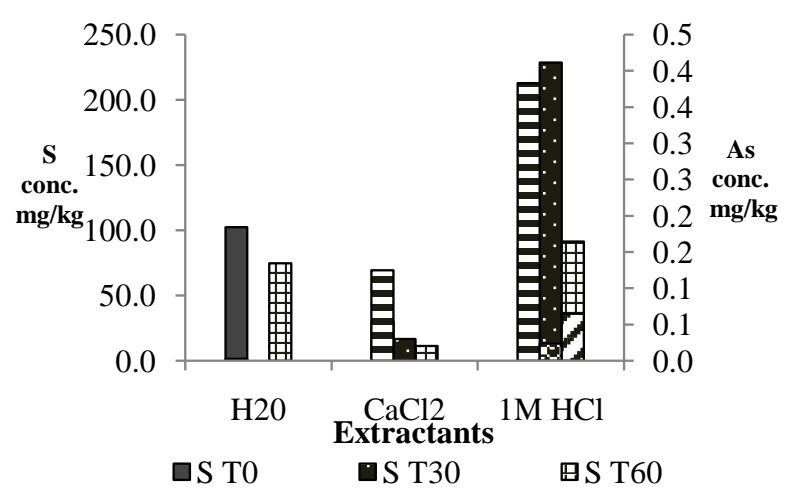

Figure 5. S-As interaction in treatment $\mathrm{As}_{0.05}$ in $\mathrm{S}_{2}$ soil.

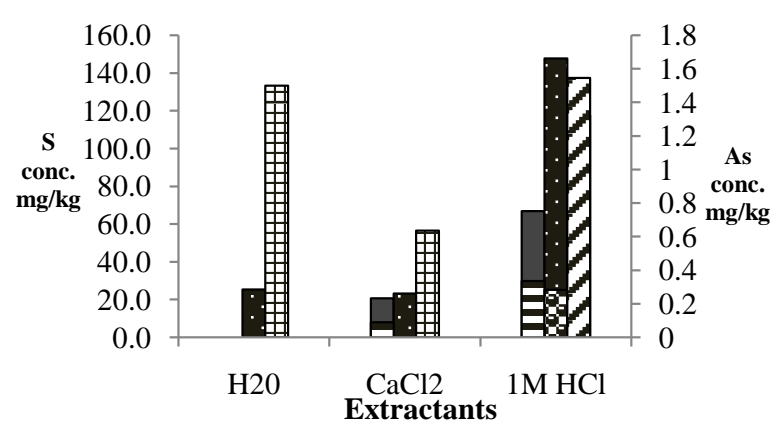

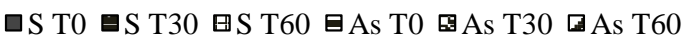

Figure 6. S-As interaction in treatment $\mathrm{As}_{1}$ in $\mathrm{S}_{2}$ soil. 
It was found that higher the As treatment, lesser was the S concentration obtained with the extraction. It might be due to the fact that $S$ undergoes chemical reactions with As. It was observed in the study that when there was more As, lesser amount of S could be extracted. Previous research showed that, microorganisms play a very important role in the biogeochemical cycles of As [19] and S [20] and consequently, in the mobilization and immobilization processes of As in the environment. If a concurrent microbial reduction of As and Sulphur takes place, the biomineralization of As will occur and as a result, As-S complexes will be formed [21].

\subsection{Interaction of S and As and Plant Growth}

The germination, growth and visual appearance of the rice plants were observed. A reddish color along with stunted growth of root was found and roots felt slippery to touch because of As toxicity. The intensity of reddish color was increased with increasing As treatment. This might be due to the formation of Fe precipitates or because of the Fe plaque formation on the root surface of the rice [22]. Besides, microbial attack was observed through physical appearance during growth of the plant.

\subsubsection{Accumulation of As in Rice}

Arsenic finds its way into soils used for rice (Oryza sativa) cultivation through As contaminated ground water irrigation. Uptake of arsenic by BRRI 41 is presented in Table 3 . Uptake is calculated by multiplying total concentration with dry matter production of plant.

It is observed from Table 3 that As concentration was greater in root with increasing doses of As. Similar result was found byShaibur et al, [23] and Yamane [24]. Generally, anions are strongly adsorbed to the membrane surface of the roots. The As anions (arsenite and arsenate) may rapidly be adsorbed onto the root surface, leading to the intense high As concentration [25]. However, only in case of the highest As treatment, stem of rice accumulated more As than the root.

\subsubsection{Accumulation of Sulphur (S) in Rice}

The concentration and uptake of $S$ by rice plant is presented in Table 4 .

It is observed from Table 4 that, concentrations of $S$ in root decreased gradually with increasing concentration of As treatments. The opposite result was found in stem, where concentration of $\mathrm{S}$ was increased with increased As treatments. Arsenic treatment at a rate of $0.05 \mathrm{mg} \cdot \mathrm{L}^{-1}$ resulted in the maximum accumulation of $\mathrm{S}$ in root, stem and grain rather than the treatment of $1 \mathrm{mg} \cdot \mathrm{L}^{-1}$.

The interactions between $S$ with As in different parts of plants are represented in Figures 7-9. There was no significant relation between $S$ and As. It is clear that plant stem contained much more $\mathrm{S}$ than As. So far about the concentration of As, rice roots contained more than the stem while the opposite was true for $\mathrm{S}$. The result is supported by similar observation made with rapeseed (Brassica napus L.) by Zhong et al., [26]. Thus the

Table 3. Concentration and uptake of As in rice.

\begin{tabular}{|c|c|c|c|c|c|}
\hline \multirow{2}{*}{ As treatment } & \multicolumn{4}{|c|}{ Concentration of As (mg/kg) } & \multirow{2}{*}{$\begin{array}{l}\text { Uptake of As } \\
\text { ( } \mu \mathrm{g} / 100 \text { plant })\end{array}$} \\
\hline & Root & Stem & Grain & Total plant & \\
\hline $\mathbf{A s}_{0}$ & 2.5 & 0.67 & 0.64 & 3.9 & 113.8 \\
\hline $\mathbf{A s}_{0.05}$ & 3.0 & 1.3 & 1.7 & 6.0 & 982.4 \\
\hline$A s_{1}$ & 5.3 & 8.0 & 0.66 & 13.8 & 871.7 \\
\hline
\end{tabular}

Table 4. Concentration and uptake of $\mathrm{S}$ in rice plant.

\begin{tabular}{|c|c|c|c|c|c|}
\hline \multirow{2}{*}{ As treatment } & \multicolumn{4}{|c|}{ Concentration of S (mg/kg) } & \multirow{2}{*}{$\begin{array}{l}\text { Uptake of S } \\
\text { ( } \mu \mathrm{g} / 100 \text { plant })\end{array}$} \\
\hline & Root & Stem & Grain & Total Plant & \\
\hline $\mathbf{A s}_{0}$ & 30696 & 12923 & 28719 & 72338 & 2136882 \\
\hline $\mathbf{A s}_{0.05}$ & 28732 & 13294 & 33484 & 75510 & 12353592 \\
\hline $\mathbf{A s}_{1}$ & 24700 & 14037 & 24169 & 62907 & 3965038 \\
\hline
\end{tabular}




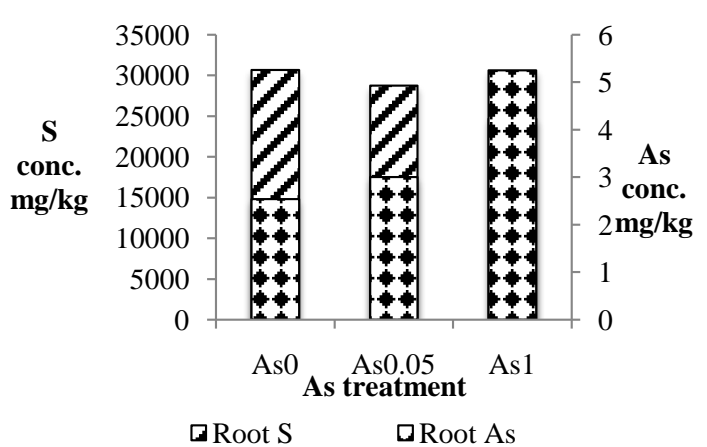

Figure 7. S-As concomitant movement in root of rice.

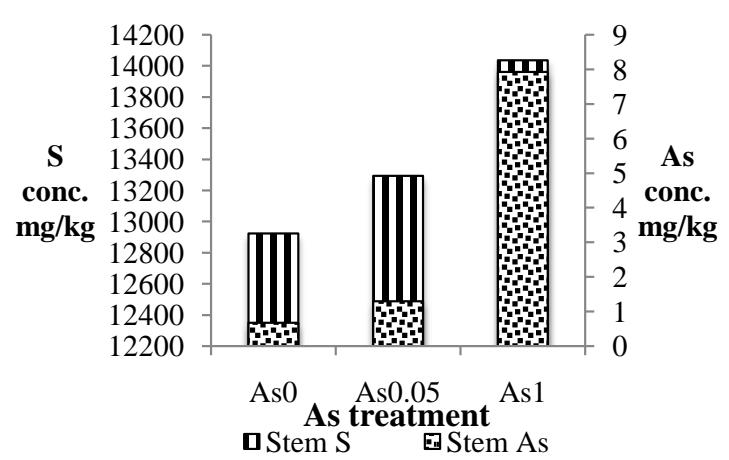

Figure 8. S-As concomitant movement in stem of rice.

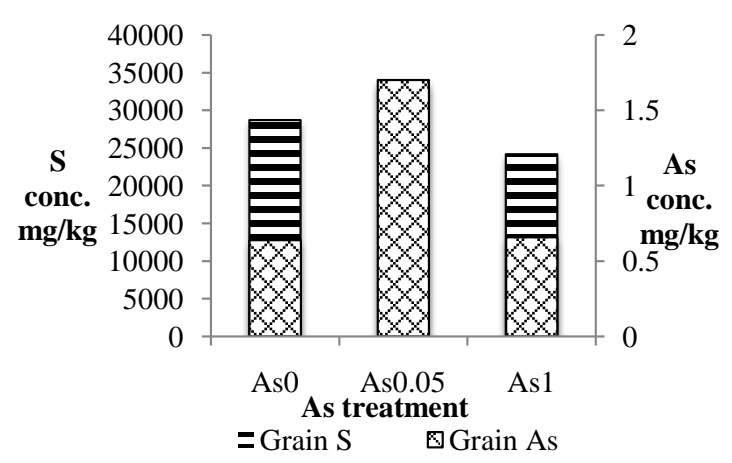

Figure 9. S-As concomitant movement in grain of rice.

presence of excess amounts of $\mathrm{S}$ in soil medium might be taken up by plants and it might also reduce the content of As in stem and leaves. This is because of the fact that, Arsenic has a high affinity with sulfur, it can exert its toxicity to plants after reduction to arsenite (As III), through interaction with thiol (-SH) groups of proteins, amino acid and enzymes [27] [28]. Moreover, excessive S supply increased the formation of iron plaque (found in visual observation) on the root surface under As stress. Iron plaque may be a barrier or a buffer to the uptake of As [29]. Again, excessive S supply may decrease As availability by forming indiscerptible $\mathrm{As}_{2} \mathrm{~S}_{3}$ or FeAsS. Bacterium, such as Desulfotomaculum auripigmentum, was reported to induce precipitation of $\mathrm{As}_{2} \mathrm{~S}_{3}$ by its reduction of As (V) to As (III) and S (VI) to S (-II) under anoxic conditions with excessive S [30]. As a result of these mechanisms individually or combined, excessive $\mathrm{S}$ present in soil could significantly alleviate As uptake and accumulation in rice exposed to As treatment.

\section{Conclusion}

The present study found an antagonistic relationship between As and S present in saline soil. Excessive $\mathrm{S}$ was not found to be detrimental to plant growth rather it reduced the amount of As in plant by different mechanism. 


\section{References}

[1] Tripathi, R.D., Srivastava, S., Mishra, S., Singh, N., Tuli, R., Gupta, D.K. and Maathuis, F.J.M. (2007) Arsenic Hazards: Strategies for Tolerance and Remediation by Plants. Trends in Biotechnology, 25, 158-165.

http://dx.doi.org/10.1016/j.tibtech.2007.02.003

[2] Rahman, M.M., Sengupta, M.K., Chowdhury, U.K., Lodh, D., Das, B., Ahmed, S., Mandal, D., Hossain, M.A., Mukharjee, S.C. and Pati. S. (2006) Arsenic Contamination Incidents around World. In: Naidu, R., Smith, E., Owens, G., Bhattacharya, P. and Nadebaum, P., Eds., Managing Arsenic in the Environment: From Soil to Human Health, CSIRO Publishing, Melbourne, 3-30.

[3] ImamulHuq, S.M. (2008) Fate of Arsenic in Irrigation Water and Its Potential Impact on the Food Chain. In: Ahuja, S., Arsenic Contamination of Groundwater: Mechanism, Analysis and Remediation. John Wiley \& Sons, Inc., Hoboken, New Jersey, 23-24.

[4] Stone, R. (2008) Arsenic and Paddy Rice: A Neglected Cancer Risk. Science, 321, 184-185. http://dx.doi.org/10.1126/science.321.5886.184

[5] Srivastava, S., Penna, S. and D’Souza, S.F. (2011) Redox State and Energetic Equilibrium Determine the Magnitude of Stress in Hydrilla verticillata upon Exposure to Arsenate. Protoplasma, 248, 805-815.

http://dx.doi.org/10.1007/s00709-010-0256-z

[6] SRDI (Soil Resource and Development Institute) (2012) Salinity Status of Bangladesh. Soil Resource and Development Institute, Dhaka, 8-20.

[7] Kowalska, I. (2005) Effects of Sulphate Level in the Nutrient Solution on Plant Growth and Sulphur Content in Tomato Plants. Folia. Horticulturae, 17, 91-100.

[8] Cerda, A., Martinez, V., Caro, M. and Fernandez, F.G. (1984) Effect of Sulfur Deficiency and Excess on Yield and Sulfur Accumulation in Tomato Plants. Journal of Plant Nutrition, 7, 1529-1543. http://dx.doi.org/10.1080/01904168409363300

[9] Komarnisky, L.A., Christopherson, R.J. and Basu, T.R. (2003) Sulphur: Its Clinical and Toxicologic Aspects. Nutrition, 19, 54-61. http://dx.doi.org/10.1016/S0899-9007(02)00833-X

[10] Fitzerald, M.A., Ugalde, T.D. and Anderson, J.W. (2001) Sulphur Nutrition Affects Delivery and Metabolism of S in Developing Endosperms of Wheat. Journal of Experimental Botany, 52, 1519-1526. http://dx.doi.org/10.1093/jexbot/52.360.1519

[11] USDA (United States Department of Agriculture) (1951) Soil Survey Manual. Soil Survey Staff, Bureau of Plant Industry, Soils and Agricultural Engineering, United States Department of Agriculture, Washington. Handbook No. 18, 205.

[12] Imamul Huq, S.M. and Alam, M.D. (2005) A Handbook on Analyses of Soil, Plantand Water. BACER-DU, University of Dhaka, Bangladesh, xxii-246.

[13] Ahnstom, Z.S. and Parker, D.R. (1999). Development and Assessment of a Sequential Extraction Procedure for the Fractionation of Cadmium. Soil Science Society of American Journal, 63, 1650-1658. http://dx.doi.org/10.2136/sssaj1999.6361650x

[14] Australian and New Zealand Environment and Conservation Council (ANZECC) and Agriculture and Resource Management Council of Australia and New Zealand (ARMCANZ), 2000. Australian and New Zealand Guidelines for Fresh and Marine Water Quality. ANZECC and ARMCANZ, Canberra, 1-103.

[15] Chowdhury, M.T.A., Nesa, L., Kashem, M.A. and ImamulHuq, S.M. (2010) Assessment of the Phytoavailability of Cd, $\mathrm{Pb}$ and $\mathrm{Zn}$ Using Various Extraction Procedures. Pedologist, 53, 80-95.

[16] Rabbi, S.M.F., Rahman, A., Islam, M.S., Kibria, K.Q. and ImamulHuq, S.M. (2007) Arsenic Uptake by Rice (Oryza sativa L.) in Relation to Salinity and Calcareousness in Some Saline Soils of Bangladesh. Dhaka University Journal of Biological Science, 16, 29-39.

[17] BARC (Bangladesh Agricultural Research Council) (2012) Fertilizer Recommendation Guide. Bangladesh Agricultural Research Council (BARC), Farmgate, Dhaka, 84-274.

[18] Portman, J.E. and Riley, J.P. (1964) Determination of Asenic in Seawater, Marine Plants and Silicate and Carbonate Sediments. Analytica Chimica Acta, 31, 509-519. http://dx.doi.org/10.1016/S0003-2670(00)88870-4

[19] Oremland, R.S. and Stolz, J.F. (2003) The Ecology of Arsenic. Science, 300, 939-944.

[20] Little, B.J., Ray, R.I. and Pope, R.K. (2000) Relationship between Corrosion and the Biological Sulfur Cycle: A Review. Corrosion, 56, 433-443. http://dx.doi.org/10.5006/1.3280548

[21] Freire, L.R., Field, J.A. and Alvarez, R.S. (2012) Arsenic Biomineralization: The Role of the Sulfur Cycle in Preventing Arsenic Groundwater Contamination. Technology and Research Initiative Fund 2011/2012. Water Sustainability Graduate Student Fellowship Program, 2012. 
[22] Batty, L.C. and Younger, P.L. (2003) Effects of External iron Concentration upon Seedling Growth and Uptake of Fe and Phosphate by the Common Reed, Phragmites australis (Cav.) Trin ex. Steudel. Annals of Botany, 92, 801-806. http://dx.doi.org/10.1093/aob/mcg205

[23] Shaibur, M.R., Kitajima, N., Sugawara, R., Kondo, T. and Kawai, S. (2006) Physiological and Mineralogical Properties of Arsenic-Induced Chlorosis in Rice Seedlings Grown Hydroponically. Soil Science and Plant Nutrition, 52, 691-700. http://dx.doi.org/10.1111/j.1747-0765.2006.00085.x

[24] Yamane T. (1989) The Mechanisms and Countermeasures of Arsenic Toxicity to Rice Plant. Bulletin of Shimane Agricultural Experiment Station, 24, 1-95.

[25] Wauchope, R.D. (1983) Uptake, Translocation and Phytotoxicity of Arsenic in Plants. In: Lederer, W.H. and Fensterheim, R.J. Eds., Arsenic: Industrial, Biomedical and Environmental Perspectives, Van Nostrand Reinhold, New York, 348-377.

[26] Zhong, L., Hu, C., Tan, Q., Liu, J. and Sun, X. (2011) Effects of Sulfur Application on Sulfur and Arsenic Absorption by Rapeseed in Arsenic-Contaminated Soil. Plant Soil Environment, 57, 429-434.

[27] Abedin, M.J., Feldmann, J. and Meharg, A.A. (2002) Uptake Kinetics of Arsenic Species in Rice Plants. Plant Physiology, 128, 1120-1128. http://dx.doi.org/10.1104/pp.010733

[28] Meharg, A.A. and Rahman, M.M. (2003) Arsenic Contamination of Bangladesh Paddy Field Soils: Implications for Rice Contribution to Arsenic Consumption. Environmental Science and Technology, 37, 229-234. http://dx.doi.org/10.1021/es0259842

[29] Liu, W.J., Zhu, Y.G., Smith, F.A. and Smith, S.E. (2004) Do Iron Plaque and Genotypes Affect Arsenate Uptake and Translocation by Rice Seedlings (Oryza sativa L.) Grown in Solution Culture. Journal of Experimental Botany, 55, 1707-1713. http://dx.doi.org/10.1093/jxb/erh205

[30] Newman, D.K., Beveridge, T.J. and Morel, F. (1997) Precipitation of Arsenic Trisulfide by desulfotomaculum auripigmentum. Applied and Environmental Microbiology, 63, 2022-2028. 